\title{
生体物質の高精度な分離を志向した高性能分析法の構築
}

\author{
加藤 大
}

\section{Development of High Efficiency Separation Method for Biomolecules}

\author{
Masaru KATO \\ Center for NanoBio Integration, Department of Applied Chemistry, Graduate School of Engineering, \\ The University of Tokyo, Room 251A, The Faculty of Engineering Building No. 3, \\ 7-3-1 Hongo, Bunkyo-ku, Tokyo 113-8656, Japan
}

(Received July 5, 2007)

\begin{abstract}
It is becoming increasingly important to separate mixed samples, such as bio- and environmental samples. For the analysis of a target compound in a mixed sample, a highly efficient and selective separation method is required. We have developed columns of high resolution, very selective columns, and highly efficient analytical methods using integrated techniques and biomolecules. These developed methods save analytical time, sample volume, etc. We are now interested in nano scale materials which many people are now focusing on. Although excellent nano materials have been developed by many researchers, there are few efficient separation, purification or evaluation methods for these compounds. In this review, we introduce our recent achievements concerning the separation of nano compounds.
\end{abstract}

Key words—— biomolecule separation; integrated chemistry; amyloid; hydrogel; sol-gel

\section{1.はじめに}

近年，分析技術の発展により，既存の分析法では 測定できなかった生命情報の解析が可能となり，新 しい知見の発見や学問領域の開拓が行われている. 例えば，生体内に存在する多数の物質の動態や機能 を明らかにするゲノミクス，プロテオミクス，メ夕 ボロミクス等の研究が可能となり，新しい生体物質 の調節機能などが報告されている.

高性能な分離法としてクロマトグラフィー法や電 気泳動法等が利用され，特に生体物質のような不揮 発性物質の分離計測には主に HPLC 法やキャピラ リー電気泳動（CE）法が利用されている。さらに HPLP と CE とを組み合わせたキャピラリー電気ク ロマトグラフィー（CEC）法，超高圧液体クロマ トグラフィー法やマイクロチップを用いた分析法な ど新しい手法が開発され，迅速に，より多成分の解 析が可能となっている。しかし，現在報告されてい る中で最も優れた分析法を用いても，地球上に存在

東京大学ナノバイオ・インテグレーション研究拠点/大 学院工学系研究科応用化学専攻（T113-8656 東京都文 京区本郷 7-3-1)

e-mail: kato@cnbi.t.u-tokyo.ac.jp

本総説は, 平成 19 年度日本薬学会奨励賞の受賞を記念

して記述したものである.
する数十万種類以上の合成化合物はおろか, 細胞に 含まれている数千種類の物質を 1 回の分析で測定す ることはできない，したがって，混合試料中の各成 分を迅速，正確に測定するには，より高分離能若し くは高選択な分離カラムや手法の開発が必要である.

分子量の小さい化合物と比較して, 高分子化合 物, ナノ粒子, 分子機械等の比較的大きな物質を, その構造を維持した状態で効率的に分離精製するこ とは難しいと考えられる，今後ナノテクノロジーの 研究で, 機能の優れた新しいナノ材料が創出される と期待されていることから，ナノサイズの物質の分 離精製法の開発は急務である。そこでこれらの物質 の分離に関するわれわれの研究についても簡単に紹 介する.

2. ゾルーゲル反応を利用した高分離能カラム

近年，モノリス型カラムと呼ばれる一体型の多孔 質体を固定相としたカラムが開発され，市販される

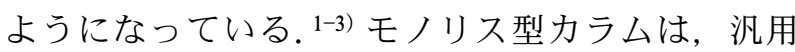
されている球状の粒子を充填したカラムとは異なつ た特性を持つカラムとして注目を集めている，その 大きな特徵は, 充填型カラムの場合は充填剤がカラ ムから流出しないようにフリットと呼ばれる栓をカ ラムの両端に作製し，2つのフリット間に充填剂を 
隙間なく充填する必要がある，そのため，粒子間の 空隙の大きさは充填する粒子の大きさによって決定 される，それに対し，モノリス型のカラムでは，固 定相を形成する骨格と空隙を形成する貫通孔の大き さを任意に制御できることから，目的の大きさの貫 通孔を有するカラムの作製が可能である，骨格や貫 通孔の大きさの調製には，一般的にスピノーダル現 象が利用されている。スピノーダル現象とは，均一 な溶液内で生じた濃度ゆらぎが自発的にその振幅を 増していく現象である。生じた濃度ゆらぎをそのま ま固定することで，同一孔径の貫通孔を有する多孔 質体が調製される。モノリス型カラムを調製する材 料として，シリカなどの無機物質 2 やアクリルアミ ドやグルタルアルデヒドのような有機化合物3)が利 用されているが，筆者らは耐圧性に優れたシリカを 主に利用している. シリカ製モノリス型カラムは, アルコキシシランを出発原料とし, 加水分解し, 重 合する過程でポロジェンと呼ばれるポリエチレング リコール（PEG）等の物質を共存させることで調 製される．充填型カラムは，粒子径数 $\mu \mathrm{m}$ の粒子を 必要な長さ充填する必要があるのに対し，モノリス 型力ラムは溶液を充填したのち，必要な領域のみを 光や熱で重合反応を行うことで固定相が調製できる ことから，非常に簡便であり実用的なカラムの調製 法である。したがって細管内に長い固定相を作製す るときにこの特徵は有効である.

ヒトゲノム配列の解読が終了した現在，生命科学 の次の研究ターゲットは, ゲノムにより制御されて いるタンパク質や情報伝達物質などの生体内物質の 動態や機能に移ってきた。これらの生体内物質は遺 伝子と酵素の発現量に基づいて産出されており，一 方で遺伝子の発現を制御している。 そのため，遺伝 子やタンパク質の発現量のみならず，タンパク質が 生産する全代謝物を網羅的に測定し，遺伝子発現や 酵素活性との関係を解明し，生体内での物質の動態 や機能を解明するメ夕ボローム研究に注目が集まつ ている.

しかし，代謝物質の多くはイオン性が高く，UV 吸収もなく不揮発性である。また物理的・化学的性 質が類似しており，さらに細胞内に千種類以上が低 濃度で存在するため，これらの代謝物を網羅的に分 析するのは非常に困難である．現在，利用されてい る代謝物の測定法には, GC-MS, ${ }^{4)} \mathrm{NMR},{ }^{5)}$ フーリ
工変換共鳴質量分析計 (FT-ICR-MS) , 6) キャピラ リ一電気泳動-質量分析計 $(\mathrm{CE}-\mathrm{MS})^{7)}$ などがある. しかしいずれの手法でも，生体内物質を網羅的に測 定することはできず，限定された化合物しか測定で きない。その中で CE-MS 法7) は，一度の分析で測 定できる化合物の種類や数が比較的多いため, メ夕 ボローム解析には最も適していると考えられる。こ の手法の問題点は，陽イオン性物質と陰イオン性物 質の分析を異なつた分析条件で別々に測定する必要 がある点であり，さらに陰イオン性物質でも核酸類 は別の条件で分析しているのが現状である。それに 加えて, CE では分離できない非イオン性物質の測

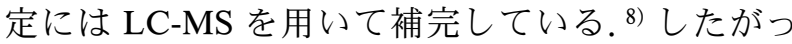
て，既存の優れた手法で網羅的な測定を行うには, 1 つの試料を少なくとも 4 種類の条件で測定する必 要があることから，超微量試料の網羅的測定には利 用できず，手間を要するなどの問題があった。そこ で筆者らは，イオン性・非イオン性物質が一斉に分 離可能な測定法の開発を行っている. CE は，同じ 荷電を有する化合物の分離には適しているが，異な つた荷電を有する化合物は，異なった方向に移動す るため, 質量分析装置などカラムで分離され溶出し てきた物質を連続的に検出する手法では検出するこ とができない。そこで CEC 法に注目した，CEC 法 は，固定相を有するキャピラリーカラム内で電気泳 動を行い，さらに必要に応じて圧力を利用して分離 溶液を送液する分析法である。電気泳動の優れた分 離能を維持しながら，圧力を利用することで異なっ た荷電を有する化合物も一緒に分析し，オンライン で質量分析装置等の装置に導入することが可能であ る.また非イオン性化合物も，固定相との相互作用 や親和性の違いによって分離され，分離溶液の流れ によって移動するため, 同一条件で分離することが できると期待された，つまり，CE では不可能なイ オン性・非イオン性物質の一斉分離が可能となる。

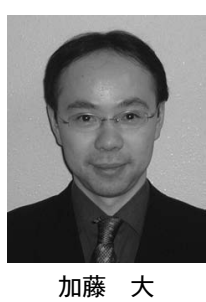

東京大学ナノバイオ・インテグレーシ ヨン研究拠点, 大学院工学系研究科特 任准教授．東京都生まれ．東京大学薬 学部卒業, 同大学院薬学系研究科博士 課程修了, 博士 (薬学)。1999 年ス夕 ンフォード大学化学科博士研究員, 2000 年静岡県立大学講師, 2006 年より 現職. 2002-2006 年さきがけ研究代表 者（JST）を兼任 
そこで CEC 用の高分離能を示すモノリス型カラ ムの開発を行った. ${ }^{9-14)}$ 多数のカラムを調製し, 最 適な固定相の構造を明らかとし，さらに分離条件を 検討することで，陽イオン，陰イオン，非イオン性 化合物を一斉に分離するカラム，及び分離条件を開 発した (Fig. 1). 15) 移動相に $1 \mathrm{M}$ ギ酸溶液を用いる ことで，アミノ酸はカルボキシル基の解離が抑制さ れアミノ基のみが解離するため，陽イオンとして振 舞い，7-8 分付近に検出された。 それに対して，中 性物質である尿素やチオウレアは 10 分付近に, リ ン酸基を有し陰イオンとして振る舞うATP は 14 分付近に検出された．現在，さらに多数の物質の同 時分析に成功し，実際に細胞内の生体物質の網羅的 測定を行っている.

\section{3. 高含水ゲルを用いて生体物質を固定化した選 択性の優れたカラム}

上記のような幅広い化合物に対して高分離能を示 し，混合試料中の成分を網羅的に測定可能な力ラム に加えて，標的化合物に対して高選択性を示す分離 カラムの開発も行っている. 選択性の優れたカラム を作製するために，タンパク質をカラムの認識部位 に利用することにした，タンパク質は，大きさは約 $10 \mathrm{~nm}$ 以下のものがほとんどであり，生体内で正確 かつ効率的に物質を認識し，さらに物質変換や情報 伝達など生体内で様々な機能を司っている，タンパ ク質を固定化したカラムとして，既に，光学分割用 や精製用カラムなどが市販されているが，そのほと んぞは化学結合を用いてタンパク質をカラム内に固

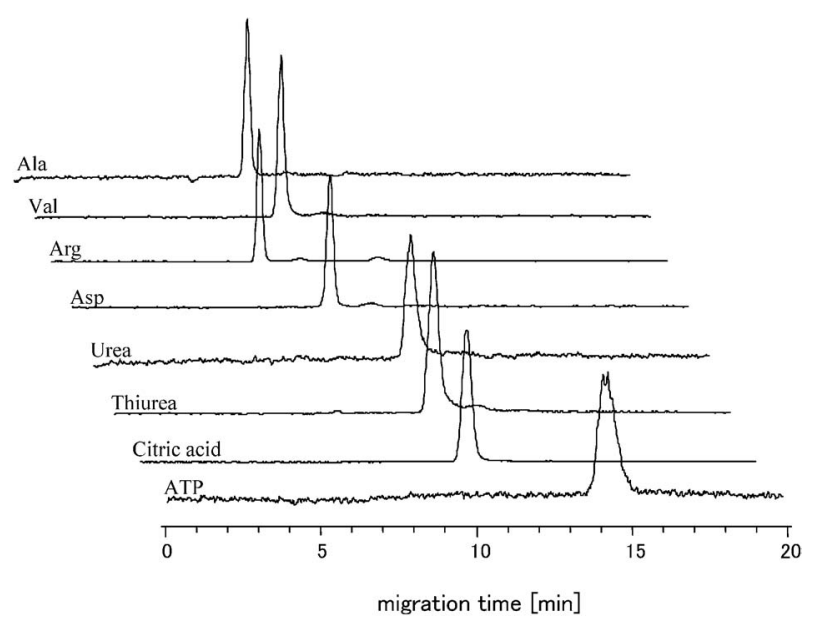

Fig. 1. Selected Ion Electropherograms for a Mixture Sample (cationic, anionic, and neutral compounds) on Monolith Capillary Column
定化している。 しかし化学結合で固定化した場合, 主にタンパク質のアミノ基やチオール基が固定化に 利用されるため，それらの官能基が活性部位に存在 する場合には，固定化によってタンパク質の機能が 変質，消失する可能性があることから，固定化して 利用できるタンパク質は限られている。 そこで筆者 らは,ゾルーゲル反応を用いたタンパク質の固定化 法を開発した。 ${ }^{16)}$ ゾルーゲル反応とは，溶液のゾル がゲルへと相転移する反応である。ゾルーゲル反応 によって生体物質を固定化するには，生成したゲル が生体物質を保持するような網目構造を有し，さら に緩和な生理的な条件で相転移反応が進行する必要 がある。そこでモノマー物質として，室温若しくは 低温条件でも重合反応が進行し，さらに加水分解の 過程で生じるアルコールが最も極性の大きいテトラ メトキシシラン（TMOS）を選択した. タンパク質 の中には，有機溶媒によって変性するものもあるた め，TMOS をモノマーに用いることで固定化する タンパク質に与えるダメージを最低限に抑えること ができる，重合条件などを調節することで，緩和な 条件で生成する高含水ゲルを利用してタンパク質を 固定化するカラムの作製法を開発した（Fig. 2). 固定化に利用する高含水ゲルの含水量が生体内の水 分量に類似しているため，固定化されたタンパク質 は長期間その機能をゲル内で保持していた。目的の タンパク質の効率的な固定化には，タンパク質毎に 条件を変化させる必要があるものの，分子量や等電 点の異なる 6 種類のタンパク質（アルブミン，オボ ムコイド，トリプシン，ペプシン，グルクロン酸ト ランスフェラーゼ，チトクロム P450）の固定化に 成功した. ${ }^{17-26)}$ アルブミンを固定化したカラムでは Trpが，オボムコイドを固定化したカラムでは塩基 性薬物であるクロロフェニラミンやエペリゾンが光 学分割された (Fig. 3). ${ }^{16,19)}$ 光学異性体を光学分割 用カラムで分離した場合，分離は溶質と固定相との 間で形成される光学活性な相互作用の安定化エネル ギーの差によって行われる。 そこで光学異性体の泳 動時間の差から結合エネルギーの差を計算した結 果，他の方法で求めた結合エネルギーの差の值に近 似していた。このことから本カラムは, 溶質の分離 に加えて結合エネルギーの差の測定にも利用できる ことが示唆された。 


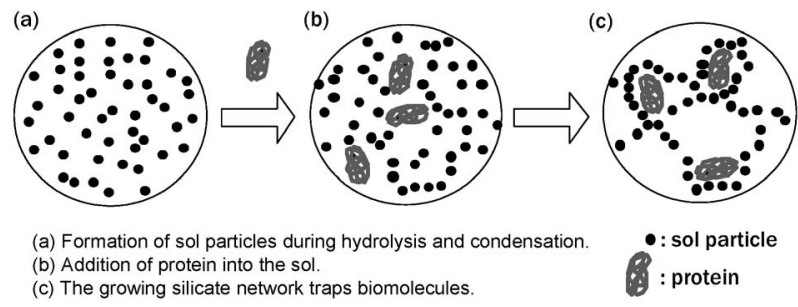

Fig. 2. Schematic Representation of Protein Immobilization Using the Sol-gel Reaction

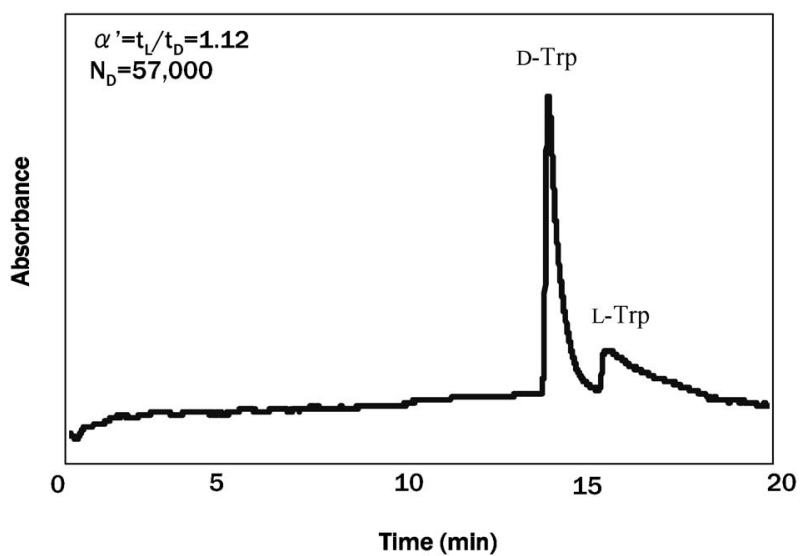

Fig. 3. Enatiomeric Separation of Trp Using Albumin Immobilized Column

\section{4. 酵素反応, 分離, 検出を集積化したカラム}

上記のタンパク質固定化カラムを用いることで, 低分子化合物の光学分割に成功した. しかし高含水 ゲルが形成する網目より大きい化合物は, 網目構造 を透過できないため，分析することができなかっ た．そこでカラム内に試料が移動するための貫通孔 を有するモノリス型カラムを作製することにした. まず，調製条件を調節してキャピラリー内に試料が 十分透過できる，大きさ数 $\mu \mathrm{m}$ の貫通孔を有する多 孔質体を作製した。次に，その多孔質体表面に前記 の高含水ゲルを用いて生体物質を被覆し，カラムを 調製した.

カラムに固定化する酵素として, タンパク質の消 化酵素であるペプシンを選択した。ペプシンは胃の 中に存在するタンパク質分解酵素であり，酵素活性 の至適 $\mathrm{pH}$ は強酸性である。分離溶液を強酸性とす ることでカラム内壁に存在するシラノール基の解離 を抑制でき，タンパク質などの試料がカラム内壁へ 吸着するのを抑制することができる。ペプシン固定 化カラムの調製は，まず光反応を利用して細管の一 端 $5 \mathrm{~cm}$ に多孔質体を調製した。その後，多孔質体
表面に TMOS を利用してペプシンを被覆し，カラ ムを調製した．カラムの残りの領域は中空とし，電 気泳動によって生成物や未反応物を分離するカラム として利用した．調製したカラムでは，固定化した ペプシンよりも大きな物質の分析も可能となり, 多 孔質体を通過する過程で，その表面に存在する固定 化されたペプシンと相互作用し酵素反応による加水 分解が効率的に進行した。本カラムでタンパク質や ペプチドなどを分析した場合，まず試料を細管に導 入すると（Fig. 4(a))，多孔質体に固定化されたぺ プシンにより酵素消化され（Fig. 4(b))，多数のペ プチド断片が生成する。次に，生成したペプチド断 片や未消化の試料などがカラムの残りの領域で電気 泳動により分離される (Fig. 4(c))．最後にカラム 内で分離された試料が，UV 検出器若しくは MS な どにより検出される。ペプチドやタンパク質を分析 した結果，固定化したペプシンの酵素活性は非常に 高く, タンパク質が $5 \mathrm{~cm}$ のペプシン固定化領域を 通過するだけで，同定に必要なペプチド断片が生成 した. ${ }^{22)}$ 繰り返し分析した場合にも活性の大幅な減 少はみられず，30 回以上の測定が可能であった. インスリン $\beta$ 鎖とリゾチームを分析した結果，そ れぞれアミノ酸配列の 100 及び $73 \%$ が検出され， 試料の同定に成功した（Fig. 5). 22) 本論文では，紙 面の都合上，酵素を固定化したカラムとしてペプシ ン固定化カラムのみについて紹介したが，その他に もトリプシン18)やグルクロン酸トランスフェラー ゼ17,23)を固定化したカラムも作製した。これらの酵 素固定化力ラムを用いることで，1 本の細管内で酵 素反応，分離，検出，さらには競合反応の解析等を 迅速，簡便に行うことに成功した。

筆者らは，このように高分離能を示すカラムや選 択性の優れたカラム等を多数開発してきた。 それら のカラムの詳細については，筆者らが最近執筆した 総説に記載したのでそちらを参照して頂きたい. ${ }^{27)}$

\section{5. 酵素固定化多孔質体}

開発した固定化法は，カラム以外の支持担体への 生体物質の固定化にも利用できると考え, 多孔質シ リカへの応用を試みた，多孔質体シリカは，無機質 のシリカより構成されるため, 物理的な衝撃に強 く，また表面積が大きいことから固定化酵素の優れ た支持担体である，多孔質シリカは，スピノーダル 現象を利用することで簡便に調製でき，さらに調製 
条件を変化させることで骨格と貫通孔の大きさを任 意に調製することができる，本検討では，表面に固 定化するタンパク質としてトリプシンを用いた。 ト リプシン固定化多孔質体の酵素活性や耐久性を効率 的に評価するために，市販の 96 穴マルチウエルプ レートの各ウエルに適合するように直径 $4.5 \mathrm{~mm}$ 程 度の円筒形の多孔質体を調製し，プレートリーダー で酵素活性を測定した. ${ }^{28)}$

Figure 6 に，調製条件を変化させて作製した多孔 質シリカの電子顕微鏡写真を示した。このように反 応溶液中の水やPEG の量を変化させることで, 多 孔質体の形状が変化し，調製条件によっては多孔質 が生成しない，若しくは脆くて酵素活性の評価に利 用できない条件もあった。調製した多孔質体の表面 は，塩基で再融解することで数 $\mathrm{nm}$ の微細孔が調製

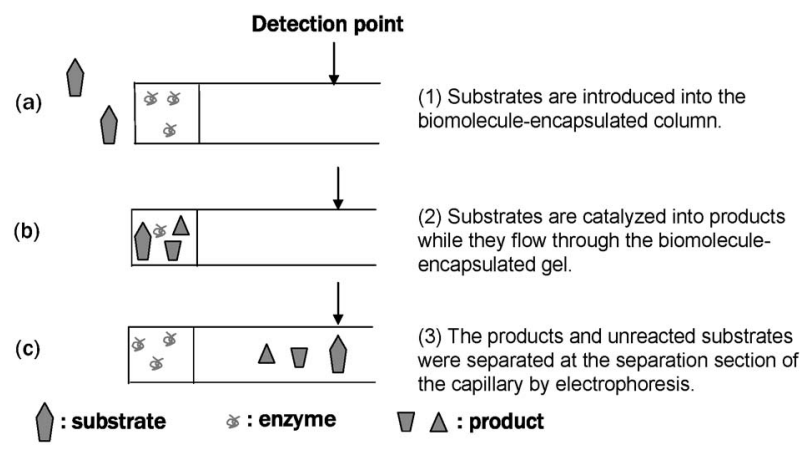

Fig. 4. Schematic Representation of Separation, Enzyme Reaction, and Detection by Enzyme-encapsulated Column
できるため，固定化する生体物質に適合した微細孔 を作製することも可能である.

初めに PEGの量や添加するメチルトリメトキシ シラン（MTMS）の割合などを変化させた多孔質 体を調製し，固定化に適した多孔質体の構造を調べ た。最適化した固定化トリプシンの $K_{\mathrm{m}}$ と $V_{\max }$ は，同量のトリプシンを溶解して反応させた際の $K_{\mathrm{m}}$ 及び $V_{\max }$ の值と類似していた。 しかし，トリプ

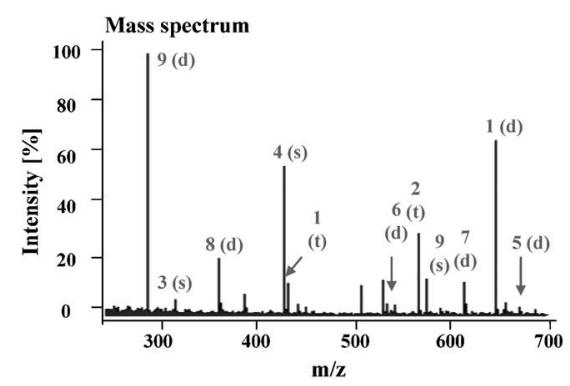

List of peptides from the on-line digestion of insulin

\begin{tabular}{|c|c|c|c|}
\hline peak & peptide & sequence & $\mathrm{MH}^{+}\left(\mathrm{MH}^{+}\right.$calc $), \mathrm{Da}$ \\
\hline 1 & $1-11$ & (-)FVNQHLC $\left(\mathrm{SO}_{3} \mathrm{H}\right) \mathrm{GSHL}$ & $1302.7(1302.6)$ \\
\hline 2 & $1-15$ & (-)FVNQHLC $\left(\mathrm{SO}_{3} \mathrm{H}\right) \mathrm{GSHLVEAL}$ & $1715.2(1714.8)$ \\
\hline 3 & $12-14$ & (L)VEA & $318.2(318.2)$ \\
\hline 4 & $12-15$ & (L)VEAL & $431.2(431.3)$ \\
\hline 5 & $15-25$ & (A)LYLVC $\left(\mathrm{SO}_{3} \mathrm{H}\right)$ GERGFF & $1351.4(1351.6)$ \\
\hline 6 & $16-24$ & (L)YLVC $\left(\mathrm{SO}_{3} \mathrm{H}\right) \mathrm{GERGF}$ & $1091.6(1091.5)$ \\
\hline 7 & $16-25$ or $17-26$ & $\begin{array}{c}\text { (L)YLVC }\left(\mathrm{SO}_{3} \mathrm{H}\right) \text { GERGFF } \\
\text { or } \\
\text { (Y)LVC }\left(\mathrm{SO}_{3} \mathrm{H}\right) \text { GERGFFY }\end{array}$ & $1238.6(1238.6)$ \\
\hline 8 & $25-30$ & (F)FYTPKA & $726.4(726.4)$ \\
\hline 9 & $26-30$ & (F)YTPKA & $579.3(579.3)$ \\
\hline
\end{tabular}

Conditions: Sample: $0.4 \mathrm{mM}$ insulin. PSG monolith: $5 \mathrm{~cm}$. Total length: $90 \mathrm{~cm}$.

Fig. 5. Insulin Analysis Using Pepsin Immobilized Column

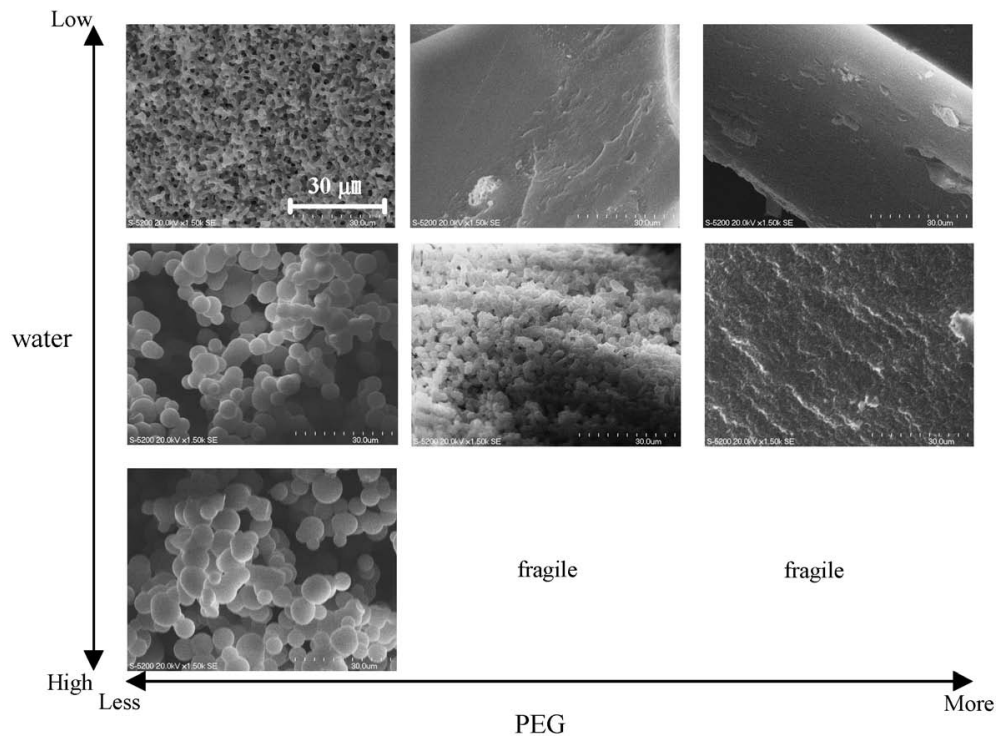

Fig. 6. Effect of Preparation Conditions on the Monolith Structure 
シンは, タンパク質の加水分解酵素であるため, 溶 解すると自己消化反応が進行し，活性が 1 日以内で ほぼ消失するのに対し，固定化した酵素は繰り返し 使用できた．これは高含水ゲルに固定化されること で，トリプシン同士の接触が抑えられ，自己消化反 応が抑制されたためと考えている．酵素固定化素子 は，洗浄するだけで 1 週間以上活性が変化すること なく, 再利用可能であった，また，必要に応じて有 機溶媒で洗浄しても活性の低下はみられなかったこ とから，耐久性や有機溶媒に対する耐性が上昇し た。さらに冷蔵庫で保管した場合には, 数カ月以上 酵素活性を維持していた.

\section{6. アミロイドの分離}

上記のようにアミノ酸などの低分子化合物から， タンパク質等の高分子化合物までは，既存の手法や 筆者らの開発した手法を用いることで良好に分離す ることができるようになってきている，しかし，さ らに大きな数 $\mathrm{nm}$ から十数 $\mu \mathrm{m}$ の物質に対して優れ た分離法があまり存在しないのが現状であると筆者 らは考えている。一般的にこのような大きな物質を 分離するには，超遠心やセルソーターなどが汎用さ れているが，これらの手法では対象物質の微小な差 異で高精度に分離することは難しい，そこで現在， 筆者らは時間とともに構造が変化し, 数 $\mu \mathrm{m}$ の線維 状物質に成長するアミロイド重合体の分離法を開発 している.

アルツハイマー病患者の脳内には, $\beta$ アミロイド $(\mathrm{A} \beta)$ 等が重合し生成する老人斑と呼ばれる沈着物 が存在していることから, $\mathrm{A} \beta$ の重合とアルツハイ マー病とは密接な関連が存在すると考えられてい る. ${ }^{29)} \mathrm{A} \beta$ は，健常人にも存在する膜タンパク質 （アミロイド前駆体タンパク質, APP）が $\beta$ 及び $\gamma$ セクレターゼによって加水分解されることで生成す る約 40 アミノ酸のペプチドである (Fig. 7). A $\beta$ を生理的な条件に放置すると非常に速やかに重合 し, 断面が数 $\mathrm{nm}$ の線維状の物質に変化し, その長 さは時間とともに成長し数 $\mu \mathrm{m}$ に達すると報告され

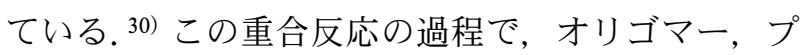
ロトフィブリルなどの複数の異なった構造を経てい ると言われているが, 重合反応が非常に速やかに進 行するため各段階の重合体の物性や動態についての

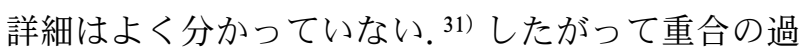
程を詳細に解明するには，重合体の迅速な測定法の

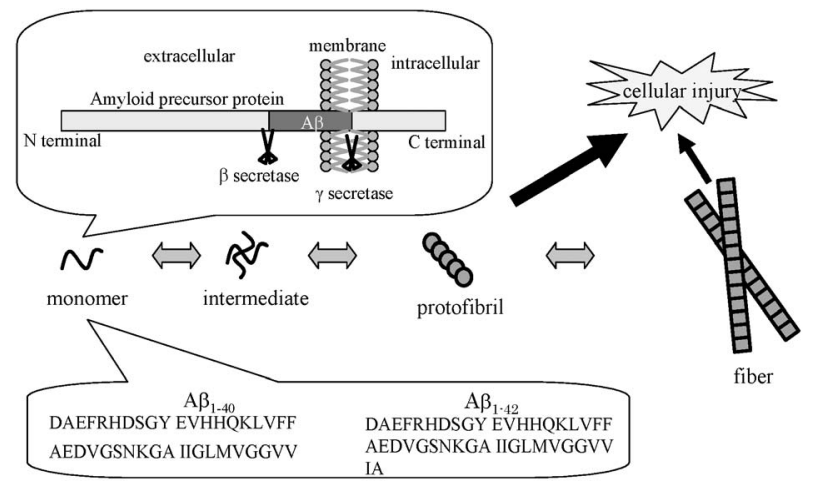

Fig. 7. Sequence of $\mathrm{A} \beta$ and Aggregation Scheme of the $\mathrm{A} \beta$

開発が必要である.アルツハイマー病患者から $\mathrm{A} \beta$ が重合した老人斑が検出されることから，この生成 を阻害する物質がアルツハイマー病の治療薬になる 可能性が高く, 重合体の詳細な解析はアルツハイ マ一病治療薬の開発につながると期待される.

筆者は, 重合過程で生成する微量成分を高感度に 検出するためにレーザー蛍光検出を選択し， $\mathrm{A} \beta$ 重 合体を選択的に検出するために蛍光試薬に Thioflavin T (Th T) を用いることにした. Th T は, $\mathrm{A} \beta$ 重合体が形成する $\beta$ シート構造と結合すること で蛍光波長（445 nm から $485 \mathrm{~nm})$ が変化すること が知られていた。 したがって Th T によって重合し た $\mathrm{A} \beta$ のみが選択的に高感度に検出される. しかし，

$\mathrm{Th} \mathrm{T}$ は, $\mathrm{A} \beta$ の重合反応を阻害する物質としても 知られていたため, $\mathrm{A} \beta$ のモノマーを溶解させた反 応溶液には Th T を添加せず, 分離溶液のみに $\mathrm{Th}$ T を添加することで, Th T が重合反応に与える影 響を排除し，より生理的な条件下で重合反応を測定 する手法を開発した。分離には，中空のキャピラ リーを用いた CE を用いた。 まず初めに分離溶液の みに $\mathrm{Th} \mathrm{T}$ を添加したときに, カラム内で $\mathrm{A} \beta$ 重合 体の蛍光標識及び分離が速やかに進行するかを確認 した. あらかじめ重合させた $\mathrm{A} \beta$ を試料に用いて分 析した結果, $\mathrm{A} \beta$ の重合体は速やかに標識され， 5 分以内に鋭いピークとして検出されたことから, 蛍 光標識及び分離を極めて短時間で行うことができ た. ${ }^{32)}$

次に, 重合反応のシード依存性について検討した. $\mathrm{A} \beta$ は，モノマー溶液を生理的な条件に放置すると 重合体が生成するが，反応液にシードと呼ばれる， 既に重合したアミロイドを添加すると重合速度が加 
速されることが知られており，この性質をシード依 存性と呼ぶ． $\mathrm{A} \beta$ のモノマー溶液にシードを添加す ると，その直後から鋭いピークが検出されたのに対 し，シード無添加のモノマー溶液では重合体の生成 に時間を要したことから (Fig. 8), 本法でも $\mathrm{A} \beta$ の シード依存性が確認された。 ${ }^{32}$

上記のように重合反応を阻害する物質は，アルツ ハイマー病の治療薬として利用できる可能性が大き いことから，開発した手法を用いて生成する重合体 のピークの変化を調へ，その変化量を比較すること で，効率的に治療薬のシード化合物が探索できると 考えた。阻害作用の測定は，まずモノマー溶液に阻 害効果が期待される物質を添加し，その後重合反応 を加速するためにシードを添加し $37^{\circ} \mathrm{C}$ に加温し， 経時的に CE で生成した重合体を測定した．測定法 の有効性を検証するために，阻害作用が報告されて いるメラトニン，3-インドールプロピオン酸，ダ ウノマイシンを阻害剤としてモノマー溶液に添加し た。 その結果，これらの化合物を添加することで， 鋭いピークが検出されるまでに要する時間が延長 し，また生成するピーク強度が減少した（Fig. 9). 32) このことは添加した化合物によって重合反応 が阻害され，重合体の形成に時間を要し，またその 量も減少したことを示していると考えられる．特に ダウノマイシンを添加した場合には，24 時間以内 に鋭いピークは検出されず，重合体の生成が強く阻 害された。今回使用した 3 種類の化合物では，阻害 作用が強い化合物ほど，生成する重合体由来のピー クが小さくなったことから，本手法は阻害剤，治療 薬の探索に有効であることが示唆された。汎用され ている $\mathrm{A} \beta$ の重合体の測定法は，まず $\mathrm{A} \beta$ のモノ
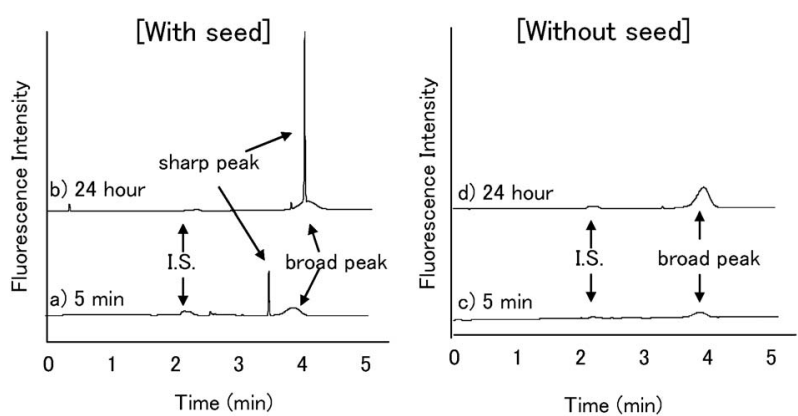

Fig. 8. Electropherograms of Fibrils (a, b) with and (c, d) without Seed for Different Incubation Times (a) and (c): $5 \mathrm{~min},(\mathrm{~b})$ and (d) $: 24 \mathrm{~h}$.
マー溶液を重合し，その後反応液に Th T を添加 し，重合体に由来する蛍光強度をプレートリーダー や分光光度計などで測定している．しかしこの手法 では，重合体の総量しか測定できず，重合度や構造 の異なった重合体を区別して測定することはできな い. それに対し本法は，2 種類以上の重合体を分離 し，それらを 5 分程度で測定することに成功してい る.したがって分離した各ピークの変化量を解析す ることで，重合体の種類に応じた阻害剤の探索が可 能になると期待している.

\section{7. 澱粉誘導体を利用した分離}

近年，分析等の化学操作をマイクロチップといわ れる微細加工した基板上に集積する試みに注目が集 まっている（Fig. 10(a)). ${ }^{33,34)}$ 化学操作を集積化す ることで, 分析時間の短縮や環境負荷の低減等に加 えて，最近では微小空間ならではの現象を利用した 高効率な抽出など，既存のマクロスケールとは異な つた物性を利用した化学操作を行う場として利用さ れ始めている. ${ }^{35)}$ 筆者らも，マイクロチップを用い ることで，より迅速に簡便に生体試料が分析できる と考え，マイクロチップを用いた分析法の開発を行 っている.

分離等の化学操作を行うマイクロチップには, 石 英等のガラス類とポリメチルメタクリレート （PMMA）やポリシロキサン等のプラスチック類の 大きく分けて 2 種類の材料が利用されている．プラ スチック製マイクロチップは，ガラス製マイクロチ ップと比較して, 安価であり, 軽く, 物理的な衝撃 にも強いことから，使い捨てでの利用や試料採取現 場での測定などに適しており，より実用化に適して

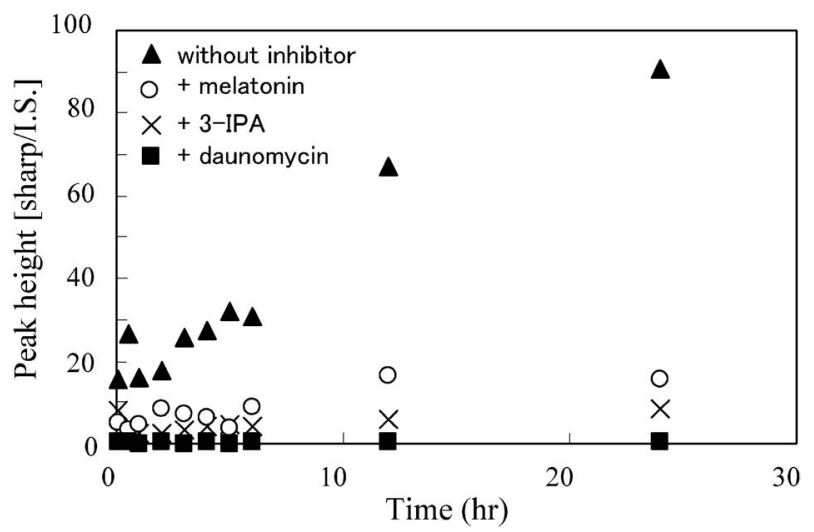

Fig. 9. Inhibitory Activity Assay Using the Three Inhibitors 
a)

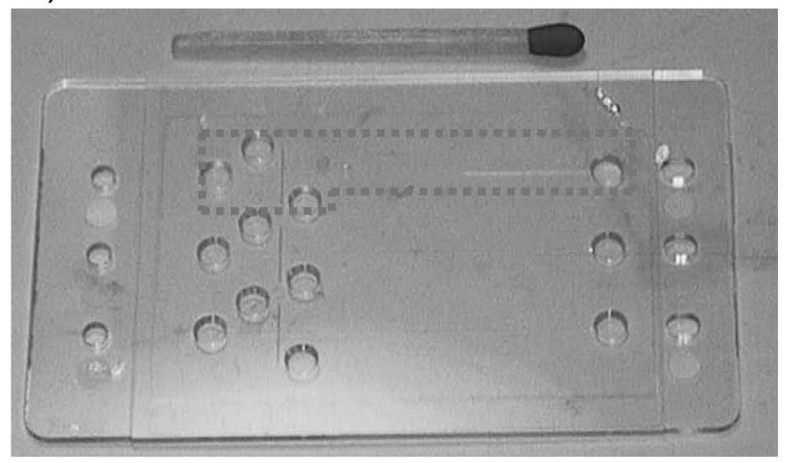

b)

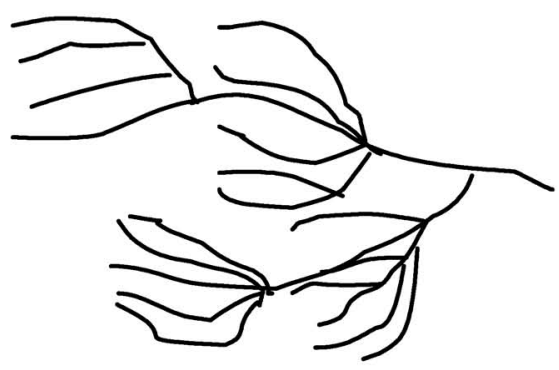

c)

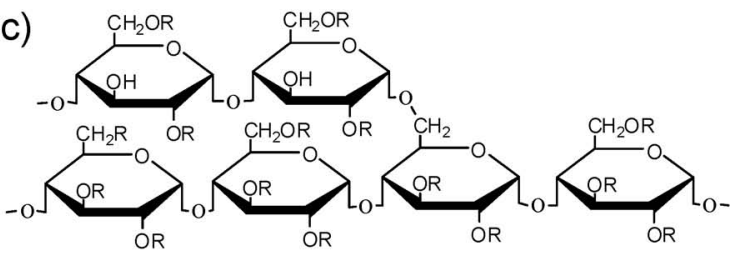

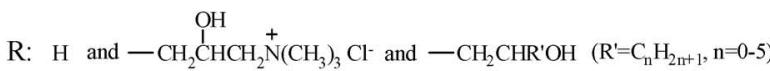

Fig. 10. Photo Image of PMMA Chip (a), Schematic Representation of Amylopectin (b), and Chemical Structure of a Cationic Starch Derivative (c)

いると考えられる。 しかし，一般的にプラスチック 表面は疎水的なため生体試料などを分析したときに は，試料がチップ表面に吸着し，測定が困難であつ た．生体内に存在する親水的な化合物であるアミノ 酸なども高感度検出のために蛍光標識化すると，チ ップ表面に吸着し，良好に分析することができなか った。このようなプラスチック製マイクロチップの 欠点を克服するために，マイクロチップ表面の性質 を改変する試みが行われている，その手法として， プラズマ照射や化学物質によるプラスチック表面の 修飾，分離溶液に吸着抑制剂を添加するなどの手法 が利用されていた。 ${ }^{36}$

筆者らは, 特別な装置が必要でなく, 簡便に再現 よくチップ表面の物性を改変できる分離溶液に吸着 抑制剤を添加する手法を用いることにした。プラス
チック製マイクロチップ表面への吸着を抑制する物 質として，既にメチルセルロースやヒドロキシプロ ピルセルロース等が知られており, 生体物質の分離

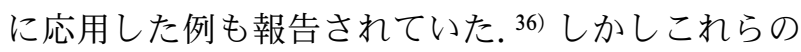
物質は CE でタンパク質などの分離に利用されてい た高分子化合物であり，水に対する溶解性が悪く， また粘度が高いためマイクロチップ内に溶解した溶 液を充填することは困難であった。そこでマイクロ チップでの利用に適した新しい抑制剤を探索する必 要があると考えた．澱粉は，セルロースと同様にグ ルコースを基本単位とする高分子化合物であり, 冷 水には溶解しづらいが, 沸騰した水には良好に溶解 し, 澱粉誘導体の中には濃度が $10 \%$ 程度の溶液も 調製可能であった。 さらに，澱粉はその構造によっ て $\alpha-1,4$ 結合によって直鎖構造を有するアミロース と $\alpha-1,6$ 結合による分岐を有するアミロペクチンに 分類することができる．特に，アミロペクチンは， 合成高分子として調製することが難しい房形構造と 呼ばれる特徵的な 2 次構造を形成していることから (Fig. 10(b)), ナノサイズの分離基材として特徴的 な機能を示す可能性を秘めていると考えている．ま た，澱粉は，多種類の誘導体が商品化されているこ とから，目的に適合した澱粉誘導体が容易に入手で きる可能性が高いと考えた。

筆者らは, カチオン, 中性, アニオン澱粉（計 20 種類）を用い, 蛍光試薬である 4-fluoro-7-nitro2,1,3-benzoxadiazole（NBD-F）で標識化したアミ ノ酸の泳動挙動を調べた. ${ }^{37)}$ 澱粉誘導体を添加して いない分離溶液を用いると良好なピーク形状が検出 されなかったのに対し，カチオン性澱粉を添加した 溶液を用いることで NBD-アミノ酸が良好に泳動さ れた. Figure 11(a)には, 3\%のカチオン澱粉を溶 解した $10 \mathrm{mM}$ リン酸緩衝液（pH 7.0）を分離溶液 に用いてアミノ酸を分析したときのエレクトロフェ ログラムを示した. カチオン性澱粉の中では修飾基 に 2-hydroxy-3- (trimethylammonio) propyl ether, chloride, 2-hydroxypropyl ether を有する澱粉誘導体 (Fig. 10(c)）が優れた吸着抑制能を有し，NBD-ア ミノ酸を良好に分離した。アミロースとアミロペク チンの比率を比較した結果，アミロースとアミロペ クチンが $2: 8$ 程度の混合比のときに最も良好な分 離結果が得られ，アミロースのみやアミロペクチン のみでは，混合した澱粉よりよい分離結果を得るこ 

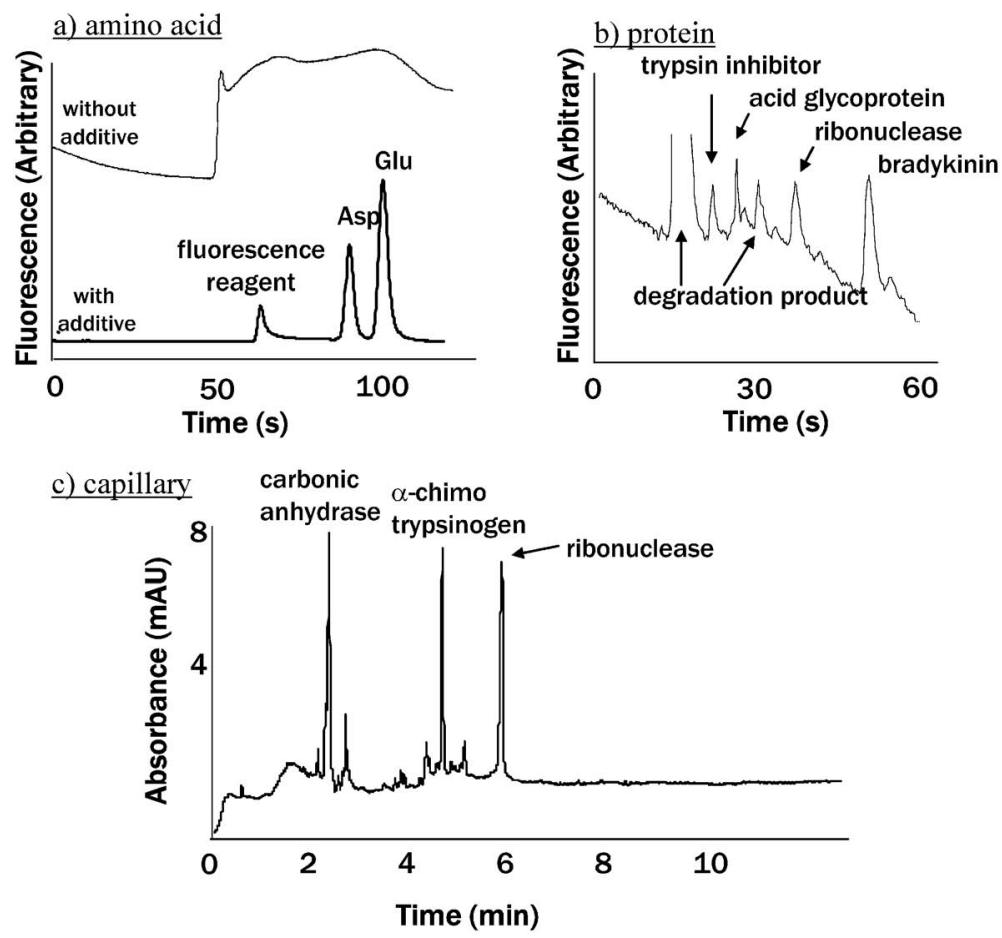

Fig. 11. Separation of Amino Acids and Proteins Derivatives Using Separation Solution Containing Starch Derivatives

とができなかった．また，カチオン澱粉の中でも， 植物より抽出した澱粉を加水分解し分子量を小さく した澱粉の方が優れた吸着抑制能を示した。溶液の 粘度が高いと，チップの流路に溶液を導入すること が困難となり，また，分離に悪影響を及ぼす泡やゴ ミ等の除去が難しく，効率的に分析できないという 問題があった。アミノ酸の中では酸性アミノ酸，続 いて中性アミノ酸の順に検出部位まで泳動された. 塩基性アミノ酸は，電圧を印加する方向を逆転（出 口側が陰極，入口側が陽極）させることで検出され た。澱粉誘導体を用いることで，プラスチック製マ イクロチップでアミノ酸を 2 分以内に分析する手法 を開発した。実際に緑茶の茶葉のアミノ酸を 2 分以 内に分析することに成功している. ${ }^{38)}$

カチオン澱粉を分離溶液に添加することで NBDアミノ酸が良好に分離されたことから，より疎水性 が高い生体物質であるペプチドやタンパク質の蛍光 標識体の分離を試みた。タンパク質試料として Trypsin inhibitor, Acid glycoprotein, Ribonuclease, Bradykinin 等を用いた結果，これらを 1 分以内に 分析することに成功した (Fig. 11(b)). ${ }^{39)}$

マイクロチップでカチオン澱粉を溶解した溶液を 用いることでタンパク質が良好に分離されたことか
ら，この分離溶液を $\mathrm{CE}$ によるタンパク質の分離に 利用した。 CE では，特に分離溶液の $\mathrm{pH}$ より高い $\mathrm{pI}$ を有するタンパク質, 塩基性タンパク質を分離 すると，試料の吸着が起こり，良好に分離すること が難しかった。この問題の解決法として，前記のペ プシン固定化カラムのときに用いた強酸性溶液を分 離溶液として用いシラノール基の解離を抑え電気的 な相互作用による吸着を抑制する方法，若しくはカ ラムの内壁を被覆し表面の官能基を変化させる方法 などが利用されている. Figure 11 (c) に $0.1 \%$ のカ

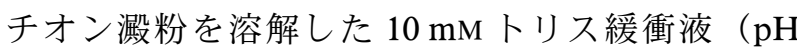
7.5）を分離溶液に用いて塩基性タンパク質を含む 異なった $\mathrm{pI}$ を持つ 3 種のタンパク質混合物（carbonic anhydrase II , $\alpha$-chymotrypsinogen A, ribonuclease A）をCE 法により分離した結果を示し た. ${ }^{40,41)}$ このように非常に鋭いピーク形状（理論段 数 560000 段 $/ \mathrm{m})$ で，短時間にタンパク質混合液を 分離することに成功した．このようにカチオン澱粉 溶液は，プラスチック製マイクロチップや融解シリ カ製キャピラリーを用いたタンパク質分離におい て，非常に優れた性質を有することが明らかとなつ た. 


\section{8. まとめ}

以上のように, 複雑な生命現象を解析するため に，より優れた分析法の開発を目指し，高分離能を 有する分離カラムや高選択性を有する分離カラムの 開発などを行ってきた。今までの研究によって，短 時間で目的成分を分析する手法の開発に成功してき たが，生体内の物質を網羅的に測定することは成功 していない。これからも優れた分析法の開発ととも に，開発した手法を用いて生命現象の解明を試みた い.

謝辞本研究は, 主に静岡県立大学薬学部薬品 分析学教室にて行ったものであり, 終始暖かくご指 導頂きました豊岡利正教授に深く感謝いたします。

また東京大学薬学部時代より御指導頂き, 分析化学 の基礎を御教授頂いた東京大学名誉教授・今井一洋 先生, 北里大学薬学部教授 - 本間 浩先生, 東京大 学准教授 - 三田智文先生, 静岡県立大学准教授 - 福 島 健先生に感謝いたします。その後のポスドク時 代から現在まで様々な御指導, 御助言を頂いている Stanford 大学教授・Richard N. Zare 先生，東京大 学教授・北森武彦先生に感謝いたします。最後に, 東大院薬, Stanford 大化学, 静岡県大薬, 東大院 工，東大 CNBI などにおける多くの共同研究者の 方々に感謝いたします。本研究の一部は，日本学術 振興会科学研究補助金, 科学技術振興機構戦略的創 造研究推進事業により遂行いたしました。ここに謝 意を表します

\section{REFERENCES}

1) Kato M., Sakai-Kato K., Toyo'oka T., J. Sep. Sci., 28, 1893-1908 (2005).

2) Minakuchi H., Nakanishi K., Soga N., Ishizuka N., Tanaka N., Anal. Chem., 68, 34983501 (1996).

3) Hjertén S., Li Y.-M., Liao J.-L., Mohammad J., Nakazato K., Pettersson G., Nature, 356, 810-811 (1992).

4) Fiehn O., Kopka J., Dörmann P., Altmann T., Trethewey R. N., Willmitzer L., Nat. Biotechnol., 18, 1157-1161 (2000).

5) Reo N. V., Drug Chem. Toxicol., 25, 375-382 (2002).

6) Kruppa G., Schnier P. D., Tabei K., Orden S.
V., Siegel M. M., Anal. Chem., 74, 3877-3886 (2002).

7) Soga T., Ohashi Y., Ueno Y., Naraoka H., Tomita M., Nishioka T., J. Proteome Res., 2 , 488-494 (2003).

8) Kato N., Soga T., Bunseki, 11, 658-660 (2004)

9) Kato M., Dulay M. T., Bennett B., Chen J.R., Zare R. N., Electrophoresis, 21, 31453151 (2000).

10) Kato M., Dulay M. T., Bennett B. D., Quirino J. P., Zare R. N., J. Chromatogr. A, 924, 187195 (2001)

11) Dulay M. T., Quirino J. P., Bennett B. D., Kato M., Zare R. N., Anal. Chem., 73, 39213926 (2001).

12) Kato M., Sakai-Kato K., Toyo'oka T., Dulay M. T., Quirino J. P., Bennett B. D., Zare R. N., J. Chromatogr. A, 961, 45-51 (2002).

13) Kato M., Jin H.-M., Sakai-Kato K., Toyo'oka T., Dulay M. T., Zare R. N., J. Chromatogr. $A$, 1004, 209-215 (2003).

14) Oguri S., Tanagaki H., Hamaya M., Kato M., Toyo'oka T., Anal. Chem., 75, 5240-5245 (2003).

15) Kato M., Onda Y., Sakai-Kato K., Toyo'oka T., Anal. Bioanal. Chem., 386, 572-577 (2006).

16) Kato M., Sakai-Kato K., Matsumoto N., Toyo'oka T., Anal. Chem., 74, 1915-1921 (2002).

17) Sakai-Kato K., Kato M., Toyo'oka T., Anal. Biochem., 308, 278-284 (2002).

18) Sakai-Kato K., Kato M., Toyo'oka T., Anal. Chem., 74, 2943-2949 (2002).

19) Kato M., Matsumoto N., Sakai-Kato K., Toyo'oka T., J. Pharm. Biomed. Anal., 30, 1845-1850 (2003).

20) Sakai-Kato K., Kato M., Nakakuki H., Toyo'oka T., J. Pharm. Biomed. Anal., 31, 299-309 (2003).

21) Sakai-Kato K., Kato M., Toyo'oka T., Anal. Chem., 75, 388-393 (2003).

22) Kato M., Sakai-Kato K., Jin H.-M., Kubota K., Miyano H., Toyo'oka T., Dulay M. T., Zare R. N., Anal. Chem., 76, 1896-1902 (2004).

23) Sakai-Kato K., Kato M., Toyo'oka T., J. Chromatogr. A, 1051, 261-266 (2004). 
24) Kato M., Saruwatari H., Sakai-Kato K., Toyo'oka T., J. Chromatogr. A, 1044, 267270 (2004).

25) Sakai-Kato K., Kato M., Homma H., Toyo’oka T., Utsunomiya-Tate N., Anal. Chem., 77, 7080-7083 (2005).

26) Sakai-Kato K., Kato M., Utsunomiya-Tate N., Toyo'oka T., “'Frontiers in Drug Design \& Discovery, Vol. 2,' ed. by Bentham Science Publishing, Bentham, 2006, pp. 273-294.

27) Kato M., Toyo'oka T., Bunseki Kagaku 56, 607-616 (2007).

28) Kato M., Inuzuka K., Sakai-Kato K., Toyo’oka T., Anal. Chem., 77, 1813-1818 (2005).

29) Dobson C. M., Trends Biochem. Sci., 24, 329332 (1999).

30) Petkova A. T., Ishii Y., Balbach J. J., Antzutkin O. N., Leapman R. D., Delaglio F., Tycko R., Proc. Natl. Acad. Sci. U.S.A., 99, 1674216747 (2002).

31) Ban T., Hoshino M., Takahashi S., Hamada D., Hasegawa K., Naiki H., Goto Y., J. Mol. Biol., 344, 757-767 (2004).

32) Kato M., Kinoshita H., Enokita M., Hori Y., Hashimoto T., Iwatsubo T., Toyo'oka T.,
Anal. Chem., 79, 4887-4891 (2007).

33) Kato M., Sakai-Kato K., Toyo'oka T., Anal. Bioanal. Chem., 384, 50-52 (2006).

34) Sakai-Kato K., Kato M., Ishihara K., Toyo’oka T., Lab. Chip, 4, 4-6 (2004) .

35) Hisamoto H., Saito T., Tokeshi M., Hibara A., Kitamori T., Chem. Commun., 24, 26622663 (2001).

36) Dang F., Zhang L., Jabasini M., Kaji N., Baba Y., Anal. Chem., 75, 2433-2439 (2003).

37) Kato M., Gyoten Y., Sakai-Kato K., Nakajima T., Toyo'oka T., Anal. Chem., 76, 67926796 (2004).

38) Kato M., Gyoten Y., Sakai-Kato K., Toyo'oka T., J. Chromatogr. A, 1013, 183-189 (2003)

39) Kato M., Gyoten Y., Sakai-Kato K., Nakajima T., Toyo'oka T., Electrophoresis, 26, 3682 3688 (2005).

40) Sakai-Kato K., Kato M., Nakajima T., Toyo'oka T., Imai K., Utsunomiya-Tate N., J. Chromatogr. A, 1111, 127-132 (2006) .

41) Kato M., Imamura E., Sakai-Kato K., Nakajima T., Toyo'oka T., Electrophoresis, 27, 18951899 (2006). 